\title{
COMPARATIVE EFFICACY OF SYNBIOTIC AND DICLAZURIL ON BROILERS EXPERIMENTALLY INFECTED WITH EIMERIA ACERVULINA
}

\author{
ALI M. ALI*; HANEM F. KHATER ${ }^{* *}$; SHAKER A. SEDDIEK ${ }^{* * *}$ and MAI O. NADA* \\ *Biochemistry, Toxicology and Nutritional Deficiency Diseases Department. Animal Health Research Institute, Benha- \\ Branch. Agriculture Research Center (ARC) \\ ${ }^{* *}$ Avian Diseases Department. Animal Health Research Institute, Benha-Branch. Agriculture Research Center (ARC) \\ **** Department of Parasitology, Faculty of Veterinary Medicine, Benha University.
}

Assiut University web-site: www.aun.edu.eg

\section{ABSTRACT}

Received at: $27 / 4 / 2015$

Accepted: 21/6/2015
The aim of this work was to use synbiotic as an alternative way to control Eimeria acervulina infections in broilers. One hundred and fifty one-day-old chicks were used. They were divided into 5 equal groups, each of 30 birds. The $1^{\text {st }}$ group was a negative control. The other groups were directly inoculated intra-crop, with $1 \times 10^{5}$ sporulated oocysts of E. acervulina on the $8^{\text {th }}$ day of age. The $2^{\text {nd }}$ group was kept as positive control. The $3^{\text {rd }}$ group was fed ration mixed with diclazuril $(1 \mathrm{ppm})$. The $4^{\text {th }}$ group was fed ration mixed with synbiotic $\left(1 \mathrm{~kg} /\right.$ ton feed). The $5^{\text {th }}$ group was fed ration mixed with diclazuril (1 ppm) plus synbiotic (1 kg/ton). Our findings revealed that, diclazuril plus synbiotic-treated group showed the superior reduction in oocyst output \& lesion score. Synbiotic-treated birds showed a significant increase in body weight, gain, feed conversion ratio, serum total protein, albumin and globulin. These birds also showed reduction in serum total cholesterol and triglycerides. It was inferred that, synbiotic could be introduced as a safe and natural tools to control coccidiosis in broilers either with or without diclazuril.

Key words: Eimeria Acervulina, Broilers, Synbiotic and Diclazuril, Comparative Efficacy.

\section{INTRODUCTION}

Avian coccidiosis is a protozoan disease caused by apicomplexon intracellular protozoan of the genus Eimeria. Currently, nine species of coccidia (from genus Eimeria) infect poultry (Chapman, 1998 and Riviere \& Papich, 2009). The most pathogenic Eimeria $(E)$ in chickens are E. acervulina, E. brunetti, E. maxima, E. mitis, E. necatrix, E. praecox, and E. tenella which can provide outbreaks of coccidiosis (Conway \& Mckenzie, 2007 and Ernik \& Bedrnik, 2001). These parasitic agents invade the mucosa, proliferate in the intestinal epithelium and provide different pathological lesions (moderate to severe) in various segments of intestine.

In the poultry industry, coccidiosis is a permanent problem; and outbreaks of coccidiosis still occur despite of the improved management conditions in broiler rearing (Cox, 1998 and Ernik \& Bedrnik, 2001).

High-intensity systems are leading to dependence on anticoccidial feed additives in broiler rearing to provide prophylactic control against infections due to pathogenetic species of Eimeria. In the modern farms, the warm humid environment due to high stocking density, provide suitable condition for Eimeria infection.
Todays, in the poultry industry, effective control of coccidiosis is still important to obtain profitable production. Coccidiosis is prevented and controlled mainly through the use of either chemical anticoccidial drugs or polyether ionophore antibiotics which still achieve sufficient control despite resistance being common.

Diclazuril is one member of chemical anticoccidial drugs. The anticoccidial efficacy of diclazuril against Eimeria spp. in broiler chickens was firstly reported in 1989 (Vanparijs et al., 1989). Diclazuril is highly and more efficacious anticoccidial drug than the other chemical and ionophorous anticoccidials in broiler chickens (Conway et al., 2001). Meanwhile, diclazuril did not interfere with development of immunity to E. brunetti, E. maxima, E. necatrix and E. tenella (Conway et al., 2002).

Although the coccidial infections have been controlled, to a great extent, with the use of anticoccidial drugs, the increase in resistance to many of these products has raised concerns about the need for new anticoccidial alternatives (Innes and Vermeulen, 2006).

Synbiotics are a mixture of probiotics and prebiotics that beneficially affects the host by improving the survival and implantation of live microbial dietary supplements in the gastrointestinal tract (Awad et al., 
2009). Probiotics are "live microorganisms which, when administered in adequate amount, confer a health benefit on the host" (FAO/WHO, 2002). A prebiotic is non-digestible food ingredients that beneficially affect the host, selectively stimulating the growth or activity, or both, of one or a limited number of bacteria in the colon (Gibson and Roberfroid, 1995).

Growth performance enhancer effects of probiotics (Ali, 2007; Awad et al., 2009 and Ezema, 2013) and prebiotics (Verdonk and van Leeuwen, 2004 and Ali, 2007) have been recorded. In addition the anticoccidial effects of probiotics (Nweze and Obiwulu, 2009; Dongjean et al., 2011; and Kyung et al., 2010) and prebiotics (Elmusharafa et al., 2007; Farag et al., 2009; Gabriela et al., 2009) have been reported.

The combination of a probiotic and prebiotic in one product has been shown to confer benefits beyond those of either on its own (Gallaher and Khil, 1999). A way of potentiating the efficacy of probiotic preparations may be the combination of both probiotics and prebiotics as synbiotics (Ali, 2007 and Awad et al., 2009).

The present study was conducted to evaluate the usage of synbiotic as an alternative way to control E. acervulina infections in broilers. The effects of synbiotic on growth performance and some biochemical parameters were determined.

\section{MATERIALS and METHODS}

\section{1- Birds}

One hundred and fifty, one-day-old apparently healthy Cobb chicks (male and female) were purchased from Al-Watania Poultry Company. The birds were allotted in separate units of metal wirefloored battery.

\section{2- Drugs}

Diclazuril (Clinacox ${ }^{\circledR} 0.5 \%$; Janssen Pharmaceutica N.V., Belgium). Mix 200 gram of Clinacox ${ }^{\circledR} 0.5 \%$ premix per ton of complete feed. This results in a final concentration of $1 \mathrm{~g}$ diclazuril per ton of feed (1 ppm) (Conway et al., 2001). To ensure thorough dispersion of the product, we mixed it with a suitable quantity $(20 \mathrm{~kg})$ of feed ingredients before incorporation in the final mix. Synbiotic (Clostat HC SP Dry®, Kemin, Belgium) contains Bacillus subtilis $2 \times 10^{8} \mathrm{CFU} / \mathrm{gm}$ (as probiotic) + Lactose $99.8 \%$ (as prebiotic). It was added to ration in a dose of $1 \mathrm{~kg} / \mathrm{ton}$ feed.

\section{3- Experimental design}

One hundred and fifty, apparently healthy, one-day old Cobb chicks were used. They were divided into five equal groups of 30 chicks each. The first group was served as a negative control (non-infected and non-treated). The other groups were directly inoculated intra-crop, using stomach tube, with $1 \times 10^{5}$ sporulated oocysts of E. acervulina on the $8^{\text {th }}$ day of age. The second group was served as a positive control (infected and non-treated). Chicks in the remaining groups were fed ration mixed with the tested drugs for six successive weeks. The third group was fed ration mixed with standard dose of diclazuril $1 \mathrm{ppm}$ ( $1 \mathrm{~g} / \mathrm{ton}$ feed). The fourth group was fed ration mixed with synbiotic at the dose of $1 \mathrm{~kg} / \mathrm{ton}$ feed. The fifth group was fed ration mixed with both diclazuril (1 ppm) plus synbiotic (1 kg/ton). The design shown in Table (1).

Table 1: Experimental design.

\begin{tabular}{|c|c|c|c|c|c|}
\hline \multirow{2}{*}{$\begin{array}{l}\text { Group } \\
\text { No. }\end{array}$} & \multirow{2}{*}{$\begin{array}{l}\text { Number } \\
\text { of chicks per } \\
\text { group }\end{array}$} & \multirow{2}{*}{\multicolumn{2}{|c|}{$\begin{array}{l}\text { Infected with } 1 \times 10^{5} \text { sporulated oocysts } \\
\text { of } E \text {. acervulina } / \text { chick }\end{array}$}} & \multicolumn{2}{|l|}{ Treatments } \\
\hline & & & & $\begin{array}{l}\text { Diclazuril } \\
(1 \mathrm{mg} / \mathrm{kg} \text { feed })\end{array}$ & $\begin{array}{l}\text { Synbiotic } \\
\text { (1g/kg feed })\end{array}$ \\
\hline 1 & 30 & - & & - & - \\
\hline 2 & 30 & + & & - & - \\
\hline 3 & 30 & + & & + & - \\
\hline 4 & 30 & + & & - & + \\
\hline 5 & 30 & + & & + & + \\
\hline \multicolumn{6}{|c|}{ Experimental infection } \\
\hline Time o & \multicolumn{5}{|c|}{ On the $8^{\text {th }}$ day of age } \\
\hline Infectiv & chick & \multicolumn{4}{|c|}{$1 \times 10^{5}$ sporulated oocysts of Eimeria acervulina } \\
\hline Route & & \multicolumn{4}{|c|}{ Directly inoculated intra-crop by the stomach tube } \\
\hline \multicolumn{6}{|c|}{ Sampling } \\
\hline Parame & & Samples/group & \multicolumn{3}{|c|}{ Time of sampling } \\
\hline Oocyst & & All birds & \multicolumn{3}{|c|}{ Daily from the $5^{\text {th }}$ To the $14^{\text {th }}$ day post infection (PI) } \\
\hline Lesion & & 5 birds & \multicolumn{3}{|c|}{ On the $7^{\text {th }} \& 14^{\text {th }}$ day PI } \\
\hline Growth & & All birds & \multicolumn{3}{|c|}{ At one-day old and then weekly till 6 weeks } \\
\hline Bioche & & 5 birds & \multicolumn{3}{|c|}{ On the $30^{\text {th }}$ day PI } \\
\hline
\end{tabular}




\section{4- Ration and water}

Chicks were fed on commercial standard balanced ration from Cairo Poultry Company without supplementation of anticoccidial drugs.

The chicks fed starter diet from 1-15 days old and then fed grower diet from 16- 25 days and finally fed on finisher diet from 25 days to marketing age (Steven and John, 2008). All diets were formulated to meet the nutrient requirement of the broilers according to recommendations of the National Research Council [NRC, 1994]. The experimental diets composition and chemical analyses of basal diet used were illustrated in table (2). The feed was sterilized in the oven at $65^{\circ} \mathrm{C}$ for 18 hours to destroy the probable accidental sporulated oocysts of Eimeria which may contaminate the rations. The water was boiled then cooled before offered to the chicks (Seddiek et al., 2008).

\section{5- Oocyst inoculation}

A field strain of E. acervulina oocysts has been previously recognized and identified in the Poultry Diseases Dept., Faculty of Vet. Med., Moshtohor, Benha University, since 2003. The strain was isolated from the duodenum of naturally infected chickens by the single oocyst isolation technique described by (Karim and Tress, 1990). The parasite was repeatedly passed in one-day old chicks every two months. The oocysts were preserved in $2.5 \%$ potassium dichromate solution (Ali et al., 2014). The chicks were inoculated intra-crop (using stomach tube) with $\left(1 \times 10^{5}\right)$ sporulated oocysts of E. acervulina on the $8^{\text {th }}$ day of age. Ten grams of the faeces were collected daily for ten successive days post inoculation (PI), starting from the $5^{\text {th }}$ to the $14^{\text {th }}$ day PI [Farag et al., 2009]. The collected droppings were preserved in potassium dichromate $(2.5 \%)$ till to be counted, using the McMaster technique (Georgi and Georgi, 1990).

\section{6- Oocysts output}

Fecal droppings were daily collected from the all birds of all groups for 10 successive days between 5-14 days post infection (PI), and the oocysts were counted in 1 gram $(\mathrm{g})$ of faecal matter by the Mc-Master technique (Georgi and Georgi, 1990). The oocyst reduction percentage was calculated according to the following formula: Reduction percentage $=(\mathrm{A}-\mathrm{B}) / \mathrm{A} \times 100$, where $A$ is the mean number of oocysts in the positive control group and $\mathrm{B}$ is the mean number of oocysts in the treated group (Ali et al., 2014).

\section{7- Lesion scoring}

On day 7 \& 14 PI, five chickens from each group were killed and lesions in the duodenum were described and scored (Johnson and Reid, 1970) as follows: Score 0: no gross lesions. Score 1: small red petechiae may appear on the serosal side of the mid intestine. There is no ballooning or thickening of the intestine, though small amounts of orange mucus may be present. Score 2: serosal surface may be speckled with numerous red petechiae, intestine may be filled with orange mucus, little or no ballooning of the intestine and thickening of the wall. Score 3: intestinal wall is ballooned and thickened. The mucosal surface is roughened and intestinal contents are filled with pinpoint blood clots and mucus. Score 4: the intestinal wall was showed ballooning for most of its length, it contains numerous blood clots and digested red blood cells, giving a characteristic colour and putrid odour; the wall is greatly thickened.

\section{8- Growth performance parameters}

The chicks were individually marked and weighed at one-day old, then body weight was recorded weekly till the end of the experiment (the sixth week). Cumulative feed consumption, cumulative body weight gains and feed conversion ratio (FCR) were calculated (Seddiek et al., 2008).

\section{9- Biochemical examinations}

Blood samples were collected from the jugular vein of five chickens per group on the $30^{\text {th }}$ day post infections. The collected samples were allowed to separate the serum and kept at - $20^{\circ} \mathrm{C}$ for estimating the activity of serum Alanine aminotransferase (ALT), Aspartate aminotransferase (AST) (Varliy, 1974), total proteins (Domas, 1975), albumin (Doumas, 1971). The serum globulin was calculated by subtracting serum albumin from serum total protein. Serum uric acid (Haisman and Muller, 1977) and creatinine (Henry, 1974), serum total cholesterol (Flegg, 1973), Triglycerides, High-density lipoprotein cholesterol (HDL-C) (Gordon et al., 1977), Low-density lipoprotein cholesterol (LDL-C) (Friedewald et al., 1972) were estimated. Very lowdensity lipoprotein cholesterol (VLDL-C) was calculated by dividing triglycerides value by 5 (Tietz, 1976). Low-density lipoprotein cholesterol (LDL-C) was calculated by the following equation: LDL-C = (Total cholesterol) - (HDL-C) - (VLDL-C) (Ashayerizadeh et al., 2009).

\section{0- Statistical analysis}

Statistical analyses were conducted with the Statistical Package for Social Science (SPSS Inc. Released, 2009) to determine if variables differed between groups, according to Snedecor and Cochran (1989). The Shapiro-Willk test was used to test the normal distribution of the data before statistical analysis was performed. Compare between means were conducted by one-way ANOVA and subsequent Duncan's multiple range test (Duncan, 1955). Probability values of less than $5 \%(\mathrm{P}<0.05)$ were considered significant.

\section{RESULTS}

Experimentally infected chickens in the positive control group showed reduced appetite, ruffled feather, dullness, diarrhea and orange coloured 
excreta. In contrast, chickens in other groups showed good performance without signs of illness.

It was noticed that, treatment with a combination of diclazuril and synbiotic (Dic+Syn) in group 5 was the most effective as it significantly $(\mathrm{P}<0.05)$ reduced the oocyst output to $11.84 \times 10^{5}$ oocysts/g excreta and increased the reduction percentage of oocyst output $(88.88 \%)$ relative to the control (Table 3$)$. On the other hand, it was found that, on the $7^{\text {th }} \& 14^{\text {th }}$ day PI, experimental treatments significantly $(\mathrm{P}<0.05)$ improved lesion score in diclazuril-treated group 3 (from 2.42 to 0.58 ), synbiotic-treated group (from 2.67 to 0.64 ), and diclazuril plus synbiotic-treated group (from 1.60 to 0.43 ). In contrast, the lesion score for positive control group was 4.21 and 4.32 on the $7^{\text {th }} \& 14^{\text {th }}$ day PI, respectively (Table 4 ).

The weekly evaluation of growth performance revealed that, Synbiotic-treated groups (group 4 \& 5) showed a significant $(\mathrm{P}<0.05)$ increase of cumulative body weight (1897.64 \& $1890.48 \mathrm{~g})$ and cumulative body weight gain (1850.54 \& $1848.71 \mathrm{~g})$.
Whereas group $4 \& 5$ showed a significant $(\mathrm{P}<0.05)$ decrease of cumulative feed consumption (3540.88 \& $3537.38 \mathrm{~g})$ and FCR (1.91 \& 1.91) when compared to the corresponding values with other groups (Table 5).

Biochemical parameters on the $30^{\text {th }}$ day PI showed that, the activity of serum ALT and AST in synbiotictreated groups (groups 4 and 5) were similar to the normal levels of negative control group. Synbiotictreated groups showed a significant $(\mathrm{P}<0.05)$ increase of Serum total protein $(6.11 \& 6.66 \mathrm{gm} / \mathrm{dl})$, albumin (3.68 \& $3.88 \mathrm{gm} / \mathrm{dl})$, globulin $(2.43 \& 2.78$ $\mathrm{gm} / \mathrm{dl})$ and HDL-C (41.2 \& $42.12 \mathrm{mg} / \mathrm{dl})$ when compared to the other groups. In contrast, synbiotictreated groups showed a significant $(\mathrm{P}<0.05)$ decrease of serum total cholesterol $(71.57 \& 70.22$ $\mathrm{mg} / \mathrm{dl})$, triglycerides (30.56 \& $30.88 \mathrm{mg} / \mathrm{dl})$, LDL-C $(24.26 \& 21.92 \mathrm{mg} / \mathrm{dl})$ and VLDL-C $(6.11 \& 6.18$ $\mathrm{mg} / \mathrm{dl}$ ) when compared to the corresponding values with other group. There was no significant difference in uric acid and creatinine among experimental groups (Table 6).

Table 2: Composition and chemical analyses of starter, grower and finisher ration used.

\begin{tabular}{|c|c|c|c|}
\hline \multirow[b]{3}{*}{ Ingredients } & \multicolumn{3}{|c|}{ Ration Type } \\
\hline & Starter & Grower & Finisher \\
\hline & \multicolumn{3}{|c|}{ 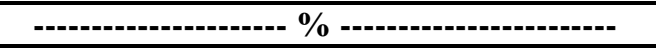 } \\
\hline Yellow corn & 61.400 & 68.300 & 73.440 \\
\hline Soya bean meal (46\%) & 29.900 & 20.300 & 15.540 \\
\hline Full-Fat soya $(35 \%)$ & 1.000 & 1.000 & 3.240 \\
\hline Corn gluten meal (62\%) & 3.500 & 6.100 & 3.740 \\
\hline DL-Methionine & 0.260 & 0.270 & 0.330 \\
\hline L-Lysine HCL & 0.265 & 0.450 & 0.470 \\
\hline L-Threonine & 0.085 & 0.085 & 0.130 \\
\hline Mono calcium phosphate & 1.170 & 1.130 & 0.750 \\
\hline Lime stone & 1.630 & 1.575 & 1.580 \\
\hline Salt & 0.240 & 0.240 & 0.230 \\
\hline Sodium bicarbonate & 0.200 & 0.200 & 0.200 \\
\hline Choline Chloride (60\%) & 0.050 & 0.050 & 0.050 \\
\hline Premix $^{1}$ & 0.300 & 0.300 & 0.300 \\
\hline \multicolumn{4}{|l|}{ Calculated chemical composition } \\
\hline Crude Protein $(\%)$ & 21.60 & 19.50 & 17.07 \\
\hline Metabolisable Energy (Kcal/kg) & 3050.00 & 3150.00 & 3200.00 \\
\hline Calcium (\%) & 0.10 & 0.95 & 0.90 \\
\hline Phosphorus (total) (\%) & 0.64 & 0.60 & 0.57 \\
\hline Available Phosphorus (\%) & 0.50 & 0.48 & 0.46 \\
\hline Methionine (\%) & 0.63 & 0.63 & 0.61 \\
\hline Lysine (\%) & 1.30 & 1.21 & 1.12 \\
\hline Threonine $(\%)$ & 0.95 & 0.85 & 0.77 \\
\hline Sodium $(\%)$ & 0.17 & 0.17 & 0.17 \\
\hline \multicolumn{4}{|c|}{ 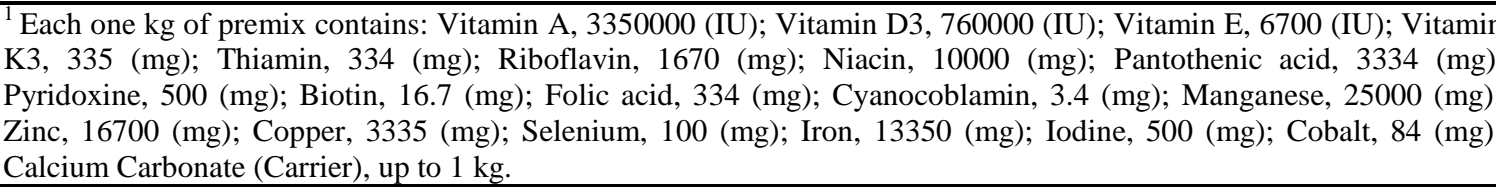 } \\
\hline
\end{tabular}


Table 3: Effect of Diclazuril or Synbiotic on oocysts output of broilers experimentally infected with Eimeria acervulina. (Mean $\times 10^{5}$ oocysts/g faeces \pm SEM).

\begin{tabular}{|c|c|c|c|c|c|}
\hline \multirow[b]{3}{*}{ Days PI } & \multicolumn{5}{|c|}{ Group } \\
\hline & 1 & 2 & 3 & 4 & 5 \\
\hline & -ve control & +ve control & Diclazuril & Synbiotic & Dic+Syn \\
\hline 5 & $0.00 \pm 0.00^{\mathrm{d}}$ & $14.26 \pm 1.17^{\mathrm{a}}$ & $8.37 \pm .27^{b}$ & $9.63 \pm 0.15^{b}$ & $6.15 \pm 0.17^{\mathrm{c}}$ \\
\hline 6 & $0.00 \pm 0.00^{\mathrm{c}}$ & $56.53 \pm 2.33^{\mathrm{a}}$ & $18.45 \pm 1.12^{\mathrm{c}}$ & $21.96 \pm 2.45^{b}$ & $11.45 \pm 0.38^{\mathrm{d}}$ \\
\hline 7 & $0.00 \pm 0.00^{\mathrm{c}}$ & $236.42 \pm 13.18^{\mathrm{a}}$ & $38.97 \pm 2.26^{\mathrm{c}}$ & $49.77 \pm 1.18^{b}$ & $36.71 \pm 2.15^{\mathrm{d}}$ \\
\hline 8 & $0.00 \pm 0.00^{\mathrm{c}}$ & $178.71 \pm 5.88^{a}$ & $75.24 \pm 2.55^{\mathrm{c}}$ & $85.10 \pm 4.22^{b}$ & $27.82 \pm 1.07^{\mathrm{d}}$ \\
\hline 9 & $0.00 \pm 0.00^{\mathrm{c}}$ & $142.34 \pm 4.54^{\mathrm{a}}$ & $58.86 \pm 1.88^{\mathrm{c}}$ & $65.97 \pm 3.45^{\mathrm{b}}$ & $16.82 \pm 0.05^{\mathrm{d}}$ \\
\hline 10 & $0.00 \pm 0.00^{\mathrm{c}}$ & $125.74 \pm 9.16^{\mathrm{a}}$ & $32.94 \pm 1.27^{\mathrm{c}}$ & $40.50 \pm 2.16^{\mathrm{b}}$ & $11.46 \pm 0.46^{\mathrm{d}}$ \\
\hline 11 & $0.00 \pm 0.00^{\mathrm{c}}$ & $108.14 \pm 7.46^{\mathrm{a}}$ & $23.22 \pm 1.46^{\mathrm{b}}$ & $25.47 \pm 1.58^{\mathrm{b}}$ & $5.23 \pm 0.24^{\mathrm{c}}$ \\
\hline 12 & $0.00 \pm 0.00^{\mathrm{b}}$ & $84.36 \pm 2.18^{\mathrm{a}}$ & $7.83 \pm 0.17^{\mathrm{c}}$ & $14.13 \pm 1.34^{\mathrm{b}}$ & $2.75 \pm 0.04^{d}$ \\
\hline 13 & $0.00 \pm 0.00^{\mathrm{b}}$ & $65.33 \pm 1.73^{\mathrm{a}}$ & $3.42 \pm 0.13^{b}$ & $3.96 \pm 1.17^{\mathrm{b}}$ & $0.00 \pm 0.00^{\mathrm{c}}$ \\
\hline 14 & $0.00 \pm 0.00^{\mathrm{b}}$ & $52.58 \pm 2.27^{\mathrm{a}}$ & $1.44 \pm 0.16^{\mathrm{bc}}$ & $2.70 \pm 1.26^{\mathrm{b}}$ & $0.00 \pm 0.00^{\mathrm{c}}$ \\
\hline Overall mean & $0.00 \pm 0.00^{\mathrm{b}}$ & $106.44 \pm 19.96^{\mathrm{a}}$ & $26.87 \pm 7.44^{\mathrm{b}}$ & $31.92 \pm 8.35^{b}$ & $11.84 \pm 3.66^{\mathrm{c}}$ \\
\hline Reduction $\%^{1}$ & --- & 0.00 & 74.76 & 70.01 & 88.88 \\
\hline
\end{tabular}

Table 4: Effect of Diclazuril or Synbiotic on lesion score of broilers experimentally infected with Eimeria acervulina. (Mean \pm SEM).

\begin{tabular}{|c|c|c|c|c|c|}
\hline \multirow[b]{3}{*}{ Time } & \multicolumn{5}{|c|}{ Group } \\
\hline & 1 & 2 & 3 & 4 & 5 \\
\hline & -ve control & +ve control & Diclazuril & Synbiotic & Dic+Syn \\
\hline The $7^{\text {th }}$ day PI & $0.00 \pm 0.00^{\mathrm{d}}$ & $4.21 \pm 0.13^{\mathrm{a}}$ & $2.42 \pm 0.46^{b}$ & $2.67 \pm 0.13^{b}$ & $1.60 \pm 0.14^{\mathrm{c}}$ \\
\hline The $14^{\text {th }}$ day PI & $0.00 \pm 0.00^{\mathrm{d}}$ & $4.32 \pm 0.26^{\mathrm{a}}$ & $0.58 \pm 0.04^{b}$ & $0.64 \pm 0.02^{\mathrm{b}}$ & $0.43 \pm 0.03^{c}$ \\
\hline
\end{tabular}

Table 5: Effect of Diclazuril or Synbiotic on some growth performance parameters of broilers experimentally infected with Eimeria acervulina. (Mean \pm SEM).

\begin{tabular}{|c|c|c|c|c|c|c|}
\hline \multirow[b]{3}{*}{ Traits } & \multirow{3}{*}{$\begin{array}{l}\text { Age } \\
\text { (day) }\end{array}$} & \multicolumn{5}{|c|}{ Group } \\
\hline & & 1 & 2 & 3 & 4 & 5 \\
\hline & & -ve control & +ve control & Diclazuril & Synbiotic & Dic+Syn \\
\hline \multirow[t]{7}{*}{$\mathrm{BW}(\mathrm{g})$} & 1 & $45.61 \pm 1.23^{\mathrm{a}}$ & $46.43 \pm 1.55^{\mathrm{a}}$ & $44.87 \pm 0.98^{\mathrm{a}}$ & $45.74 \pm 1.18^{\mathrm{a}}$ & $45.84 \pm 2.06^{\mathrm{a}}$ \\
\hline & 7 & $161.78 \pm 2.11^{\mathrm{b}}$ & $163.43 \pm 3.54^{\mathrm{b}}$ & $160.86 \pm 5.32^{b}$ & $184.26 \pm 4.37^{\mathrm{a}}$ & $185.22 \pm 4.56^{\mathrm{a}}$ \\
\hline & 14 & $342.95 \pm 5.12^{b}$ & $341.08 \pm 6.88^{b}$ & $340.42 \pm 11.46^{\mathrm{b}}$ & $379.65 \pm 6.24^{\mathrm{a}}$ & $381.87 \pm 3.77^{\mathrm{a}}$ \\
\hline & 21 & $682.75 \pm 11.75^{\mathrm{b}}$ & $610.13 \pm 15.42^{\mathrm{c}}$ & $677.35 \pm 12.25^{\mathrm{b}}$ & $744.32 \pm 22.87^{\mathrm{a}}$ & $746.32 \pm 43.76^{\mathrm{a}}$ \\
\hline & 28 & $1131.15 \pm 33.78^{\mathrm{b}}$ & $1011.91 \pm 27.29^{c}$ & $1124.86 \pm 15.98^{b}$ & $1197.98 \pm 48.53^{a}$ & $1204.33 \pm 67.11^{a}$ \\
\hline & 35 & $1473.12 \pm 69.44^{b}$ & $1309.25 \pm 77.84^{\mathrm{c}}$ & $1465.63 \pm 13.44^{\mathrm{b}}$ & $1594.14 \pm 54.44^{\mathrm{a}}$ & $1608.11 \pm 83.54^{\mathrm{a}}$ \\
\hline & 42 & $1811.70 \pm 55.72^{b}$ & $1418.27 \pm 67.34^{\mathrm{c}}$ & $1795.68 \pm 28.46^{\mathrm{b}}$ & $1897.64 \pm 72.62^{a}$ & $1890.48 \pm 73.62^{a}$ \\
\hline $\mathrm{cFC}(\mathrm{g})$ & & $3775.25 \pm 74.24^{\mathrm{a}}$ & $3346.25 \pm 73.73^{\mathrm{c}}$ & $3771.37 \pm 56.12^{\mathrm{a}}$ & $3540.88 \pm 76.14^{b}$ & $3537.38 \pm 85.44^{b}$ \\
\hline cBWG (g) & & $1766.09 \pm 23.55^{b}$ & $1369.80 \pm 33.47^{\mathrm{c}}$ & $1762.41 \pm 33.45^{b}$ & $1850.54 \pm 32.42^{\mathrm{a}}$ & $1848.71 \pm 62.37^{\mathrm{a}}$ \\
\hline $\mathrm{cFCR}$ & & $2.13 \pm 0.08^{\mathrm{b}}$ & $2.44 \pm 0.04^{\mathrm{a}}$ & $2.14 \pm 0.03^{\mathrm{b}}$ & $1.91 \pm 0.04^{\mathrm{c}}$ & $1.91 \pm 0.06^{\mathrm{c}}$ \\
\hline
\end{tabular}

${ }^{a-c}$ Mean values within the same row with different superscript letter are statistically different at $(p \leq 0.05)$. SEM: standard error of mean. Dic+Syn: Diclazuril plus synbiotic. BW: Body weight. cFC: Mean group cumulative feed consumption. cBWG: Mean group cumulative body weight gain. cFCR: Mean group cumulative feed conversion ratio. 
Table 6: Effect of Diclazuril or Synbiotic on some biochemical parameters of broilers experimentally infected with Eimeria acervulina. (Mean \pm SEM).

\begin{tabular}{|c|c|c|c|c|c|}
\hline \multirow{3}{*}{ Parameter } & \multicolumn{5}{|c|}{ Group } \\
\hline & 1 & 2 & 3 & 4 & 5 \\
\hline & -ve control & +ve control & Diclazuril & Synbiotic & Dic+Syn \\
\hline ALT (U/L) & $24.46 \pm 1.16^{\mathrm{b}}$ & $38.52 \pm 2.15^{\mathrm{a}}$ & $25.26 \pm 1.13^{\mathrm{b}}$ & $26.23 \pm 1.03^{b}$ & $25.17 \pm 1.08^{b}$ \\
\hline AST (U/L) & $53.24 \pm 1.25^{\mathrm{b}}$ & $76.28 \pm 2.37^{\mathrm{a}}$ & $51.17 \pm 2.31^{\mathrm{b}}$ & $55.47 \pm 1.17^{\mathrm{b}}$ & $56.11 \pm 1.05^{b}$ \\
\hline Total Protein $(\mathrm{gm} / \mathrm{dl})$ & $3.84 \pm 0.04^{\mathrm{b}}$ & $2.64 \pm 0.05^{\mathrm{c}}$ & $3.66 \pm 1.06^{\mathrm{b}}$ & $6.11 \pm 0.18^{a}$ & $6.66 \pm 0.08^{a}$ \\
\hline Serum Albumin $(\mathrm{gm} / \mathrm{dl})$ & $2.17 \pm 0.02^{b}$ & $1.52 \pm 0.02^{\mathrm{c}}$ & $2.12 \pm 0.08^{b}$ & $3.68 \pm 0.04^{\mathrm{a}}$ & $3.88 \pm 0.03^{\mathrm{a}}$ \\
\hline Serum Globulin $(\mathrm{gm} / \mathrm{dl})$ & $1.67 \pm 0.04^{b}$ & $1.12 \pm 0.04^{\mathrm{c}}$ & $1.54 \pm 0.06^{\mathrm{b}}$ & $2.43 \pm 0.01^{\mathrm{a}}$ & $2.78 \pm 0.04^{\mathrm{a}}$ \\
\hline Uric Acid (mg/dl) & $7.33 \pm 0.27^{\mathrm{a}}$ & $7.25 \pm 0.17^{\mathrm{a}}$ & $7.46 \pm 0.14^{\mathrm{a}}$ & $6.54 \pm 0.39^{\mathrm{a}}$ & $6.19 \pm 0.18^{a}$ \\
\hline Creatinine $(\mathrm{mg} / \mathrm{dl})$ & $1.16 \pm 0.02^{\mathrm{a}}$ & $1.06 \pm 0.02^{\mathrm{a}}$ & $1.13 \pm 0.08^{\mathrm{a}}$ & $1.12 \pm 0.04^{\mathrm{a}}$ & $1.33 \pm 0.06^{\mathrm{a}}$ \\
\hline $\begin{array}{l}\text { Total Cholesterol } \\
\text { (mg/dl) }\end{array}$ & $110.72 \pm 4.34^{\mathrm{a}}$ & $73.57 \pm 5.18^{b}$ & $118.72 \pm 7.83^{\mathrm{a}}$ & $71.57 \pm 5.15^{b}$ & $70.22 \pm 3.25^{b}$ \\
\hline Triglycerides $(\mathrm{mg} / \mathrm{dl})$ & $41.23 \pm 2.46^{\mathrm{a}}$ & $31.17 \pm 2.55^{b}$ & $42.33 \pm 3.64^{\mathrm{a}}$ & $30.56 \pm 1.64^{b}$ & $30.88 \pm 2.84^{b}$ \\
\hline HDL-C $(\mathrm{mg} / \mathrm{dl})$ & $33.12 \pm 1.38^{\mathrm{b}}$ & $30.33 \pm 2.84^{\mathrm{b}}$ & $32.87 \pm 2.79^{b}$ & $41.2 \pm 1.72^{\mathrm{a}}$ & $42.12 \pm 2.76^{2}$ \\
\hline LDL-C (mg/dl) & $69.35 \pm 4.46^{\mathrm{a}}$ & $37.01 \pm 1.45^{\mathrm{b}}$ & $77.38 \pm 4.95^{\mathrm{a}}$ & $24.26 \pm 1.47^{\mathrm{c}}$ & $21.92 \pm 1.37^{c}$ \\
\hline VLDL-C (mg/dl) & $8.25 \pm 0.68^{\mathrm{a}}$ & $6.23 \pm 0.42^{b}$ & $8.47 \pm 0.11^{\mathrm{a}}$ & $6.11 \pm 0.24^{b}$ & $6.18 \pm 0.41^{b}$ \\
\hline
\end{tabular}

${ }^{a-c}$ Mean values within the same row with different superscript letter are statistically different at $(p \leq 0.05)$. SEM: standard error of mean. Dic+Syn: Diclazuril plus synbiotic. PI = day post-inoculation. AST: Aspartate aminotransferase. ALT:

Alanine transaminase. HDL-C: High-density lipoprotein cholesterol. LDL-C: Low-density lipoprotein cholesterol. VLDL:

Very low-density lipoprotein cholesterol.

\section{DISCUSSION}

Our findings for the anticoccidial effect of the experimental treatments revealed that birds in group treated with a combination of diclazuril and synbiotic (Dic+Syn, group 5) showed a significant reduction in oocyst output compared with those infected and treated with either diclazuril or synbiotic alone. The marked reduction of oocyst output may be due to the direct effect of diclazuril on the endogenous stages of E. acervulina (sporozoites and merozoites), besides the indirect effect of synbiotic through increasing the intestinal microflora that occupying the specific receptors responsible for adherence and attachment of the invasive parasites (sporozoites and merozoites). These actions resulted in marked reduction of shedding oocysts of E. acervulina. Our results are similar to the results recorded by several authors (Stanley et al., 2004; Nollet et al., 2007; Gabriela et al., 2009 and Farag et al., 2009).

On the $7^{\text {th }} \& 14^{\text {th }}$ day PI, experimental treatments showed improvement in lesion score in diclazuriltreated and synbiotic-treated groups but diclazuril plus synbiotic-treated group showed the superior improvement than others. These findings may be attributed to the beneficial effects of synbiotic on intestinal epithelial morphology (Chalorsuntisakul et al., 2010). These results are in agreement with those recorded by many researchers (Farag et al., 2009; Chalorsuntisakul et al., 2010 and Ghasemi et al., 2010).
The beneficial effects of Synbiotic-treated groups (group $4 \& 5$ ) on broiler performance parameters including cumulative body weight, cumulative body weight gain and FCR. The use of synbiotic (mixture of probiotic plus prebiotic) could reduce the count of pathogenic bacteria and increase the population of useful microflora in gut, due to the synergistic effect between probiotic and prebiotic. Therefore, it could be concluded by removing pathogenic bacteria that can adhere to the gastrointestinal track wall, Immune system may be less stimulated and a favorable medium is provided for the use of energy and nutrients by birds (Fairchild et al., 2001). In addition, the use of synbiotic by increasing in length of the intestinal mucosa, increases the absorption areas and improves the bird's energy and protein efficiency ratio (Santin et al., 2001). Furthermore, the effect of probiotics and prebiotics on reduction of pathogenic bacteria could reduce the breakdown of proteins to nitrogen. In this way, the utilization of proteins (amino acids) is improved, particularly from food that does not contain them in optimum quantities (Mikulec et al., 1999). Finally, each of the above mentioned reasons may lead to better growth responses of broilers.

The beneficial effects of synbiotic groups on broiler performance parameters are in agreement with previous studies (Nayebpor et al., 2007; Falaki et al., 2010; Ghasemi et al., 2010 and Ashayerizadeh et al., 2011). In contrast, Gunal et al. (2006) and Willis 
et al. (2007) reported that using of synbiotic had no significant effects on growth performance of broilers.

In the present study, E. acervulina infected and not treated broilers (positive control) showed an increase of serum AST and ALT activity. These findings may be attributed to the significant damage of cell lining of intestinal wall along with their inflammation and severe blood loss causing tissue loss from the body. These results are similar to the result of Biu et al. (2006), who reported that the ALT level was increased in mixed coccidian-infected chickens. On the other hand, the present findings were different from the previous studies indicated by Mondal et al. (2011) who reported that ALT decreased in broiler chickens infected with a field isolate of E. tenella. The positive control group showed a significant decrease in serum total protein, albumen, globulin, total cholesterol, triglycerides, LDL-C and VLDL-C. the hypoproteinemia in coccidial infections may be due to acute stress that leads to cortisol section and catabolism of protein. Acute hemorrhage causes loss of plasma protein followed by rapid movement of interstitial fluid without protein into the plasma compartment to induce acute hypoproteinemia (Mondal et al., 2011). The decrease of all parameters of lipid profile may be attributed to anorexia and malabsorption of nutrients in broilers. Anorexia may be a major reason for declined triglyceride level in the coccidia affected birds. Distrurbance in B vitamin synthesis in coccidiosis may hinder lipogenesis from carbohydrate (Mondal et al., 2011). These results are in accordance with those obtained by Farag et al. (2009) and Mondal et al. (2011).

Diclazuril treated group did not show any significant difference of all examined biochemical parameters when compared with non-infected non-treated chickens. These results are in accordance with EFSA (2014).

Serum AST and ALT activity returned to normal levels in synbiotic-treated birds (groups 4\&5). These indicate that synbiotic decreases the damaging effects of coccidial infections. These agree with Farag et al. (2009). Synbiotic-treated birds showed a significant increase of serum total protein, albumin, globulin and HDL-C. These findings may be attributed to the improvement effects of synbiotic in the intestinal environment which leading to improvement of the digestion and absorption of the nutrients. In addition, the synbiotic limits the damage caused by the pathogenic parasites (Eimeria spp.) so, it may be increased the bioavailability of essential nutrients. These results are in agreement with Khodary et al. (2004) and Farag et al. (2009). In contrast, these results disagree with those obtained by Sharifi et al. (2011). On the other hand, synbiotic-treated birds showed a significant decrease of serum total cholesterol, triglycerides, LDL-C and VLDL-C. The reduction in serum total cholesterol of broilers fed synbiotic supplemented feed could be attributed to reduced absorption or synthesis of cholesterol in the gastro-intestinal tract (GIT) by synbiotic supplementation (Ghiyasi et al., 2008). Synbiotic increases the population of Lactobacillus spp. in GIT. Lactobacillus, which has a high bile salt hydrolytic activity, is responsible for de-conjugation of bile salts (Taherpour et al., 2009). De-conjugated bile acid are less soluble at low $\mathrm{pH}$ and less absorbed in the intestine and is more likely to be excreted in feces (Klaver and Van der Meer, 1993). In addition, probiotic microorganism inhibits hydroxymthylglutaryl-coenzyme A, an enzyme involved in the cholesterol synthesis (Fukashima and Nakano, 1995). The most important mechanism by which prebiotic eliminates cholesterol would likely be through reducing lipid absorption in intestine by binding bile acids, which results in increased cholesterol elimination and hepatic synthesis of new bile acid (Zhang et al., 2003, Taherpour et al., 2009). These findings are in accordance with those obtained by Ashayerizadeh et al. $(2009,2011)$ and Sharifi et al. (2011). However, Cakir et al. (2008) reported that dietary additives including synbiotic (Biomin ${ }^{\circledR}$ IMBO, Biomin GmbH, Herzogenburg, Austria) had no significant effect on triglyceride. Uric acid and creatinine did not differ between groups. These results indicated that, all experimental groups have no harmful effect on kidney functions in broilers. These findings are in consistent with the publications of Khodary et al. (2004); Farag et al. (2009) and Sharifi et al. (2011). Synbiotic could be considered as safe because it had no side effect on the liver and kidney of the treated broilers.

It could be inferred that, in challenge period no differences were detected between broilers fed either synbiotic or diclazuril. If considering; oocysts output, lesion scoring of E. acervulina, growth performance and biochemical parameters, these results suggest that, synbiotic may have positive effects either administered alone or in combination with diclazuril in broilers chickens infected with $E$. acervulina. Synbiotic could be introduced as a safe and natural tools to control coccidiosis in broilers either with or without chemical anticoccidial drugs.

\section{REFERENCES}

Ali, A.M.; Seddiek, Sh.A. and Khater, H.F. (2014): Effect of butyrate, clopidol and their combination on the performance of broilers infected with Eimeria maxima. British Poultry Science, DOI 10.1080/ 00071668. 2014.920488.

Ali M. Ali (2007): A comparative study on the effect of some growth promoters in chickens. Ph.D. thesis, Fac. Vet. Med., Zagazig Univ. 
Ashayerizadeh, A.; Dabiri, N.; Ashayerizadeh, O.; Mirzadeh, K.H.; Roshanfekr, H. and Mamooee, M. (2009): Effect of dietary antibiotic, probiotic and prebiotic as growth promoters, on growth performance, carcass characteristics and hematological indices of broiler chickens. Journal of Biological sciences 12 (1): 52-57.

Ashayerizadeh, A.; Dabiri, N.; Mirzadeh, K.H. and Ghorbani, M.R. (2011): Effect of dietary supplementation of probiotic and prebiotic on growth indices and serum biochemical parameters of broiler chickens. Journal of Cell and Animal Biology. 5(8): 152-156.

Awad, W.A.; Ghareeb, K.; Abdel-Raheem, S. and Bohm, J. (2009): Poul. Sci., 2009, 88, 49-55.

Biu, A.A.; Yusuf, S.D. and Rabo. J.S. (2006): Use of Neem (Azadirachta indica) aqueous extract as a treatment for poultry coccidiosis in Borno, Maiduguri, Nigeria. Afr. Sci.7: 3-15.

Cakir, S.; Midilli, M.; Erol, H.; Simsek, N.; Cinar, M.; Altintas, A.; Alp, H.; Altintas, L.; Cengiz, O. and Antalyali, A. (2008): Use of combined probiotic-prebiotic, organic acid and avilamycin in diets of Japanese quails. Rev. Med. Vet.-Toulouse 159: 565-569.

Chalorsuntisakul, Surawat; Sirithunyalug, Jakkapan; Chaiyasut, Chaiyavat; Aengwanich, Worapol; and Pewnim, Thanit (2010): Effect of synbiotics on caecal morphology and lesion score in broilers infected with Eimeria tenella. Avian Biology Research; 3 (4): 187-195.

Chapman, HD. (1998): Evaluation of the efficacy of anticoccidial drugs against Eimeria species in the fowl. Inter J Parasitol, 28, 1141-1144.

Conway, DP. and McKenzie, ME. (2007): Poultry Coccidiosis. Diagnostic and Testing Procedures. 3rd ed., 168, Wiley-Blackwell, Iowa, USA.

Conway, D.P.; Mathis, G.F.; Johnson, J.; Schwartz, M. and Baldwin, C. (2001): Efficacy of diclazuril in comparison with chemical and ionophorous anticoccidials against Eimeria spp. in broiler chickens in floor pens. Poult. Sci., 80: 426-430.

Conway, D.P.; Mathis, G. and Fand Lang, M. (2002): The use of diclazuril in extended withdrawal anticoccidial programs: 2- Immunity to E. tenella challenge after drug withdrawal. Poult. Sci., 81: 353-355.

Cox, FEG. (1998): Control of coccidiosis: Lessons from other sporozoa. Inter J. Parasitol, 28, 165-179.

Domas, B.L. (1975): Colorimetric determination of total protein. Clin. Chem., 21(1): 159-166.

Dongjean Yim; Sang S. Kang; Dong W. Kim; Sang H. Kim; Hyun S. Lillehoj and Wongi Min (2011): Protective effects of Aloe vera-based diets in Eimeria maxima-infected broiler chickens. Experimental Parasitology. 127(1): 322-325.
Doumas, B. (1971): Colorimetric method for albumin determination. Clin. Chim. Acta, 31: 87-92.

Duncan, D.B. (1955): Multiple range and multiple F tests. Biometrics 11: 1-42.

EFSA FEEDAP Panel (EFSA Panel on Additives and Products or Substances used in Animal Feed), (2014): Scientific Opinion on the safety and efficacy of Coxiril@ (diclazuril) as a feed additive for chickens for fattening. EFSA Journal 2014; 12(6):3728, 23 pp. doi: 10.2903/j.efsa. 2014. 3728.

Elmusharafa, M.A.; Peekb, H.W.; Nolletic, L. and Beynena, A.C. (2007): The effect of an in-feed mannan-oligosaccharide preparation (MOS) on a coccidiosis infection in broilers. Anim. Feed. Sci. Tech., 134: 347-354.

Ernik, F. and Bedrnik, P. (2001): Controlling coccidiosis in broiler growing. Poult Inter, 40, $36-42$.

Ezema, C. (2013): Probiotics in animal production: A review. Journal of Veterinary Medicine and Animal Health. 5(11): 308-316

Fairchild, AS.; Grimes, JI.; Jones, FT.; Wineland, MJ.; Edens, FW. and Sefton, AE. (2001): Effects of Hen Age, Bio-Mos, and Flavomycin on Poult Susceptibility to Oral Escherichia coli Challenge. Poult. Sci., 80: 562-571.

Falaki, M.; Shams Shargh M.; Dastar B. and Zrehdaran, S. (2010): Effects of different levels of probiotic and prebiotic on performance and carcass characteristics of broiler chickens. J. Anim. Vet. Adv., 9(18): 2390-2395.

FAO/WHO (2002): Joint FAO/WHO (Food and Agriculture Organization/ World Health Organization) Joint working group report on drafting. London, Ontario, 1-11

Farag E.A.; Ali, M. Ali; Seddiek, Sh.A. and Sabry, E.O. (2009): Comparative Efficacy Of Prebiotic Mannan-Oligosaccharide And Diclazuril In Chickens Experimentally Infected With Eimeria tenella. Zag. Vet. J. (ISSN. 1110-1458) Vol. 37, No. 5: 102 -115.

Flegg, HM. (1973): Quantitative-enzymaticcolourimetric determination of total cholesterol and HDL-C in serum or plasma. Ann Clin Biochem 10: 79-88.

Friedewald, W.T.; Levy, R.I. and Fredrickson, D.S. (1972): Estimation of the concentration of LDL cholesterol in plasma, without use of the preparative ultracentrifuge. Clin. Chem., 18: 499-502.

Fukushima, M. and Nakano, M. (1995): The effect of probiotic on faecal and liver lipid classes in rats. Brit. J. Nutr. 73: 701-710.

Gabriela, G.V.; Arturo, C.C.; Carlos, L.C.; Ernesto, A.G. and Gerado, M.N. (2009): Dietary supplementation of mannan-oligosaccharide enhances neonatal immune responses in 
chickens during natural exposure to Eimeria spp. Acta Veterinaria Scandinavica, 51: 11.

Gallaher, D.D. and Khil, J. (1999): J. Nutr., 129(Suppl. 7), 1483S-1487S.

Georgi, J. and Georgi, M. (1990): Parasitology for Veterinarians. 5th Edition, W.B. Saunders Company, Philadelphia, London, Toranto, Montereal, Sydney, Tokyo.

Ghasemi, H.A.; Shivazad, M.; Esmaeilnia, K.; Kohram, H. and Karimi, M.A. (2010): The effects of a synbiotic containing enterococcus faecium and inulin on growth performance and resistance to coccidiosis in broiler chickens. Journal of Poultry Science. 47(2): 149 -155.

Ghiyasi, M.; Rezaei, M. and Sayyahzadeh, H. (2008): Effect of prebiotic (fermacto) in low protein diet on performance and carcass characteristics of broiler chicks. Int. J. Poultry Sci.6: 661-665.

Gibson, G.R. and Roberfroid, M.B. (1995): J. Nutr., 125, 1401-1412.

Gordon, T.; Castelli, W.P.; Hjortland, M.C.; Kannel, W.B. and Dawber, T.R. (1977): High density lipoprotein as protective factor against coronary heart disease: The Framingham study. Am. J. Med., 62: 707-714.

Gunal, M.; Yayli, G.; Kaya, O.; Karahan, N. and Sulak, O. (2006): The effects of antibiotic growth promoter, probiotic or organic acid supplementation on performance, intestinal microflora and tissue of broiler. Int. J. Poult. Sci., 5: 149-155.

Haisman, P. and Muller, B.P. (1977): Glossary of clinical chemistry and terms. Butter worth, London, P126.

Henry, R.J. (1974): Clinical chemistry, principles and techniques. Second Ed., Harper and Raw, 525-531.

Innes, E.A. and Vermeulen, A.N. (2006): Vaccination as a control strategy against the coccidial parasites Eimeria, Toxoplasma and Neospora. Parasitology, 133 (Suppl.): S 145-16

Johnson, J. and Reid, W.M. (1970): Anticoccidial drugs: Lesion scoring techniques in battery and floor pen experiments with chickens. Experimental Parasitology, 28: 30-36. doi: 10.1016/0014-4894(70)90063-9.

Karim, M.J. and Tress, A.J. (1990): Isolation of five species of Eimeria in Bengldish. Tropical Animal Health Production, 22: 153-159.

Khodary, R.M.; Rezk, H.I. and Assaf, I.M.M (2004): Comparative study on enramycin, probiotic and prebiotic as growth promoters in quails. The 7th Vet. Med. Zag. Conference Sharm El Sheikh, 699-710.

Klaver, F.A.M and Van der Meer, R. (1993): The assumed assimilation of cholesterol by lactobacillus and Bifidobacterium bifidum is due to their bile salt deconjugating activity. Appl. Environ. Microbiol. 59: 1120-1124.
Kyung, W.L.; Hyun, S.L.; Seung, I.J.; Guangxing, L.; Sung-Hyen, L.; Erik, P.L. and Gregory, R.S. (2010): Effect of Bacillus-based direct-fed microbials on Eimeria maxima infection in broiler chickens. Comparative Immunology, Microbiology and Infectious Diseases. 33: 105-110.

Mikulec, Z.; Serman, V.; Mas, N. and Lukac, Z. (1999): Effect of probiotic on production results of fattened chickens fed different quantities of protein. Vet. Arhiv. 69: 199-209.

Mondal, D.K.; Chattopadhyay, S.; Batabyal, S.; Bera, A.K. and Bhattacharya, D. (2011): Plasma biochemical indices at various stages of infection with a field isolate of Eimeria tenella in broiler chicken. Vet. World. 4: 404-409.

National Research Council (NRC) (1994): Nutrient requirements of Poultry, pp. 19-26.7th ed., National academy press, Washington. D.C.

Nayebpor, M.; Farhomand, P. and Hashemi, A. (2007): Effect of different levels of direct fed microbial (Primalac) on the growth performance and humoral immune response in broiler chickens. J. Anim. Vet. Adv., 6: 1308-1313.

Nollet, L.; Huyghebaert, G. and Spring, P. (2007): Effect of dietary mannan-oligosaccharide (Bio-MOS) on live performance of broiler chickens given an anticoccidial vaccine (Paracox) followed by a mild coccidial challenge. J. Appl. Poult. Res., 16: 397-403.

Nweze, N.E. and Obiwulu, I.S. (2009): Anticoccidial effects of Ageratum conyzoides. Journal of Ethnopharmacology 122, 6-9.

Riviere, J. and Papich, MG. (2009): Veterinary Pharmacology and Therapeutics. 9th ed., 1500, Wiley-Blackwell, Iowa, USA.

Santin, E.; Maiorka, A.; Macari, M.; Grecco, M.; Sanchez, JC.; Okada, TM. and Myasaka, AM. (2001): Performance and intestinal mucosa development of broiler chickens fed diet containing Sccharomyces cerevisiae cell wall. J. Appl. Poult. Res., 10: 236-244.

Seddiek, Sh.A.; Mobarak, M.G.; Ali, M.M.A. and Metwaly, A.M. (2008): "Potentiation of Salinomycin Anticoccidial Effect with Butylated Hydroxy Toluene (BHT) In Broilers". Special Issue for $5^{\text {th }}$ Scientific Conference 21-23 October 2008. Suez Canal Vet. Med. J., Vol. XIII (2): 241-258.

Sharifi Mohammad Reza; Shams-Shargh, Mahmoud; Dastar, Behrouz and Hassani, Saeed (2011): The effect of dietary protein levels and synbiotic on performance parameters, blood characteristics and carcass yields of Japanese quail (Coturnix coturnix Japonica). Italian Journal of Animal Science.10 (4): 17-21.

Snedecor, G.W. and Cochran, W.C. (1989): Statistical methods. The eighth. Edition, Iowa University Press, Ames, Iowa, USA. 
SPSS Inc. Released (2009): PASW Statistics for Windows, Version 18.0. Chicago: SPSS Inc.

Stanley, V.G.; Gray, C.; Daley, M; Krueger, W.F. and Sefton, A.E. (2004): An alternative to antibiotic-based drugs in feed for enhancing performance of broilers grown on Eimeria spp.-infected litters. Poult. Sci., 83: 39-44.

Steven, L. and D.S. John (2008): Feeding program for Broiler chickens. Page: 229-296: Commercial Poultry Nutrition, 3rd. ed. British Library.

Taherpour, K.; Moravej, H.; Shivazad, M.; Adibmoradi M. and Yakhchali, B. (2009): Effects of dietary probiotic, prebiotic and butyric acid glycerides on performance and serum composition in broiler chickens. Afr. J. Biotechnol. 8: 2329-2334.

Tietz, N.W. (1976): Fundamentals of clinical chemistry. WB saunders Company. Washington D.C.
Vanparijs, O.; Marsboom and Rand Desplenter, L. (1989): Diclazuril, a new broad spectrum anticoccidial drug in chickens. 1- Dose titration studies and pilot floor pen trials. Poult. Sci., 68: 489-495.

Varliy, H. (1974): Clinical chemistry methodology, past and present. Ann. Clin. Chem., 11: 161-63.

Verdonk, J.M.A.J. and Van Leeuwen, P. (2004): 4th Orafti Research Conference, 12-13 Feb. Paris, France.

Willis, W.L.; Isikhuemhen, OS; and Ibrahim, A. (2007): Performance assessment of broiler chickens given mushroom extract alone or in combination with probiotic. Poult. Sci., 86: 1856-1860.

Zhang, W.F.; Li, D.F.; Lu, W.Q. and Yi, G.F. (2003): Effect of isomalto-oligosaccharides on broiler performance and intestinal micro flora. Poultry Sci. 82: 657-663.

\section{مقارنة فعالية سينبيوتك ودايكلازوريل علي دجاج اللحم المعدي تجريبياً بالأيميريا أسرفيولينا

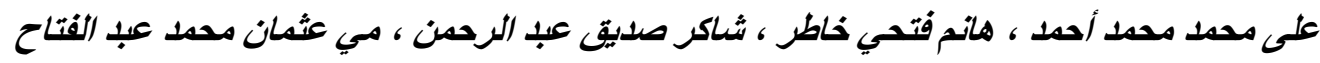

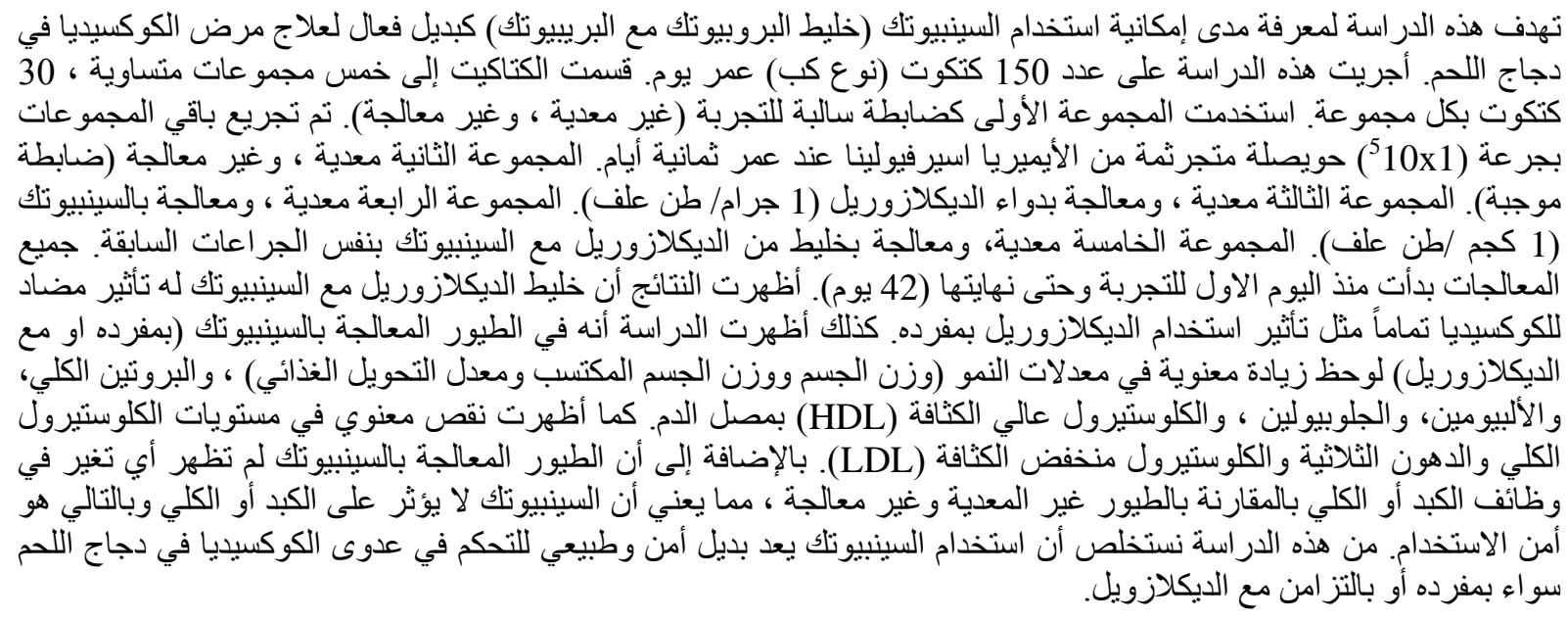

